\title{
To Establish Cultural Confidence in Teaching Reform of Foreign Language Education in Colleges and Universities
}

\author{
Ling Yang \\ College of Foreign Languages and Literature \\ Jilin Normal University \\ Siping, China
}

\author{
Shuhua Li \\ College of Foreign Languages and Literature \\ Jilin Normal University \\ Siping, China
}

\begin{abstract}
Under the guide of the 19th National Congress of the CPC, foreign language education and teaching reform in colleges and universities should strive to create an important window to face the world culture and create an important platform for cultural exchanges with foreign countries. And then, it can create an important position for promoting cultural confidence in China. To deepen the foreign language education in colleges and universities, we must always firmly adhere to the Chinese cultural standpoint, stick to the essence of cultural confidence, and construct the teaching system of foreign language dominated by Chinese discourse.
\end{abstract}

Keywords-foreign language education; Chinese culture; cultural confidence

\section{INTRODUCTION}

In the report of 19th NPC, "Culture is the soul of a nation. Culture revitalization would be helpful for the revitalization of the country. The culture is strong, and the nation would be strong. Without high-degree cultural confidence and cultural prosperity, there will have no great rejuvenation of the Chinese nation." [1] Cultural confidence has very important practical significance in the great journey of realizing the great rejuvenation of the Chinese nation. We must steadfastly hold cultural confidence and build a powerful cultural country with socialism. We must adhere to the position of Chinese culture. Based on the reality of contemporary China, it should develop scientific, popular and national socialist culture oriented toward modernization, the world and the future. In colleges and universities, foreign language education is an important window for China to face world culture. Also, it is an important platform for foreign cultural exchanges. And it is an important front for promoting cultural confidence. To deepen the reform of foreign language education in colleges and universities, we must closely integrate the characteristics of foreign cultural exchanges, firmly adhere to the position of Chinese culture, stick to the essence of cultural confidence, expand the cultivation of students' humanistic qualities, and construct the teaching system of foreign language dominated by Chinese discourse.

\section{The CURRENT Problems IN Foreign LANGUAGE EDUCATION IN COLLEGES AND UNIVERSITIES}

Foreign languages are an important tool to draw all the achievements of civilization and make the cooperation in foreign exchanges. Foreign language education takes the important functions of foreign exchange, heritage culture and social services. Foreign language education in colleges and universities plays a decisive role in strengthening students' humanistic accomplishment, enhancing students' cultural confidence and improving the cultural soft power of the nation. However, there are still some problems in foreign language education in colleges and universities in China. Many problems are not suitable for serving the national development strategy and meeting the needs of students in learning foreign languages.

\section{A. Curriculum Setting Is Excessively Dominated by the Culture of the Language, and It Lacks the Courses of Chinese Culture}

At present, there are mainly two types of foreign language education in China. One is specialized foreign language teaching, and the other is general public English teaching. All required courses for foreign language majors are related to the knowledge on the language of the foreign countries. Elective courses are also generally set for western culture. There are common courses such as "the introduction to western culture" and "western newspaper reading". However, it generally lacks the courses of Chinese culture. The curriculum is almost empty. Classroom is an important place for students to acquire knowledge. However, due to the dual deficiency of compulsory course and elective course, the students are almost impossible to learn the native expression of English in class. Basically, it loses the important way of classroom learning. That is to say, it loses important guarantee for effective learning.

\section{B. Teaching Resources such as Teaching Materials, Have Much Knowledge on the Countries of Language, and It Lacks Chinese Traditional Culture}

Studies have shown that it lacks the content related to Chinese culture in foreign language textbooks. [2] At present, 
the teaching materials of foreign language related to native culture have disadvantages in terms of types and quantity. And the performance of relevant contents in main English teaching materials is also poor. Most of the current English teaching materials in China are mainly based on British and American culture [3]. The value orientation of English teaching materials in colleges and universities is heavily inclined to European and American cultures (especially American culture). In the extra-curricular learning materials, some achievements have been made in the English translation of traditional cultural classics in China. However, the main objects in China are still the foreign readers. (Luo Xuanmin, Yang Wendi. 2012: 63-66) There are a few of mature teaching materials or teaching resources that can truly satisfy the needs of systematic learning of the vast majority of young students in China. And it takes young students as the objects of reading and education. It can be said that current English teaching materials and supplementary materials mainly focused on the "fetching doctrine". The dialectical analysis and integration of their content isn't sufficient enough. And the output of unique oriental traditional culture is not enough.

\section{In the Terms of Classroom Teaching, Extra-curricular Activities and Other Foreign Language Teaching Carriers, the Chinese Culture Loses the Speech Right}

At present, in classroom teaching, the focus of foreign language and culture teaching is still mainly on the introduction of western culture and related information. And it has paid less attention to the introduction of Chinese local culture. Foreign language teachers fail to timely recognize the necessity and importance of conducting local culture in the classroom. It would improve the soft power of the country. They often neglect the improvement of the ability to make the expression with native language. Due to lack understanding and ability, the introduction of native culture is not enough in the classroom. It lacks input in the classroom. Most of explanations and infiltration of western culture in the classroom far exceed that of local culture. At the same time, in extracurricular activities, the students have little opportunities to make cultural expression with native language. The western culture has gone throughout the relative extracurricular activities such as foreign song contest, foreign film dubbing contest and other activities. There are only a few activities that link foreign languages with Chinese traditional culture or with the development of Chinese society in real life. The useless ideas of Chinese culture are slowly spreading among students. And the students' learning motivation is gradually losing.

\section{THE CULTIVATION OF INTERCULTURAL COMMUNICATIVE COMPETENCE IN FOREIGN LANGUAGE EDUCATION}

In recent years, with the development of China's economy and culture and the continuous improvement of its international status, more and more complex high-end talents with intercultural communication skills are needed in China. In foreign language education of colleges and universities, it urgently needs to expand the humanistic connotation and pay more attention to the introduction of culture. It is the mission of serving the national strategy. And it is also the essential requirement of humane quality education.

\section{A. To Grasp Basic Functions of Foreign Language Education}

Foreign language is not only a tool of communication, but also a carrier of culture. The purpose of learning foreign language is to understand the world, exchange ideas, spread culture and enhance language ability. And the training of comprehensive humanistic quality is the key. Humboldt, a German linguist, once pointed out: "learning a foreign language means winning a new foothold in the context of formed worldview. Every language contains a complete system of concepts and imagination that belongs to a certain human group". [6] Foreign language teaching should enable students to understand, say, read and accurately. Also, the students should use foreign languages in line with the habits of the country's language. They should accurately express the speaker's thinking. The students should know their own culture. At the same time, they also know well about the culture of the language. They also have a deep understanding of the differences between the two cultures. The students would have strong intercultural communication skills.

\section{B. To Pay Attention to the Cultivation of Cross-cultural Competence in Foreign Language Education}

The main goal of cultural teaching in foreign language education is to enable students to cultivate cultural awareness and achieve cultural understanding. Then, they could have cross-cultural communication teaching and language skills simultaneously. At the same time, in the era of globalization, cultural means have become an important mean of implementing international strategies and foreign policies. It is the duty of teachers to guide students to understand and absorb the complicated cultural information in a critical way. Foreign language teaching is a part of intercultural education. It regards language as an integral part of culture and society. Foreign language teaching should closely follow the direction of world education. And the talents would have intercultural communicative competence. Through the reflection of different cultures and fusion of sight, Chinese culture will be sent to the other side of the world. Foreign language teaching should emphasize social orientation, supplement native culture, carry out the practice of cultural discourse and promote value recognition. The learners should tell Chinese stories. And it would promote conciseness of Chinese discourse and carry forward the value of China. The students would become a new generation with cultural consciousness and cultural confidence.

\section{To Encourage the Application of Critical Thinking in Foreign Language Teaching}

Foreign language teaching mainly aims at cultivating students' critical awareness and critical thinking skills in accepting foreign cultures. Through cultural comparison, the teachers should encourage students to analyze and treat foreign cultures objectively. In foreign language teaching, 
we should fully realize the importance of cultivating critical thinking ability. On the one hand, cultural study provides a platform for students to carry on critical thinking. Through the exploration and verification of knowledge, students would look at the problems from multiple perspectives. On the other hand, through critical thinking, students will break through the cultural knowledge, and deepen their thinking and understanding. And then, it would cultivate their intercultural communication and cultural critical ability. To cultivate college students' critical thinking skills is conducive to the survival and development of students in the information era. Also, it would be helpful to eliminate superstitions. [7]

\section{TO Establish the CUltural CONFIDENCE OF FOREIGN LANGUAGE EDUCATION IN COLLEGES AND UNIVERSITIES BASED ON CHINESE CULTURE}

Based on cultural confidence, the teaching reform of foreign language education in colleges and universities should pay attention to the construction of teaching resources, the relevant curriculum setting, and the reform of classroom teaching and the guidance of teachers. And then, it could carry forward the outstanding Chinese traditional culture and the core of socialism values. It would develop foreign language education in China, safeguard the interests of the Chinese nation and improve the soft power of Chinese culture.

\section{A. To View Current Logic of Foreign Language Education in Colleges and Universities, and to Enhance the Pertinence of Teaching Reform from the Perspective of Chinese Culture}

There are current problems in the foreign language education of colleges and universities. For example, in the selection of teaching materials, it lacks the literary nature, practicality and ideological and critical issues. It has much training in language skills. However, it lacks the ability to train independent thinking. In the process of teaching, there are too many explanations, expositions and infiltrations of western culture. The teachers teach little native culture. And then, it would lead to "Chinese culture aphasia" in developing students' intercultural communication. [8] Foreign language education in colleges and universities should take the initiative to deal with the challenges of multiculture. Also, it should enhance cultural confidence. It should be the power to deepen the reform. And it would enhance the relevance of education and teaching reform.

\section{B. To Enhance the Cultural Exchange of Foreign Language Education in Colleges and Universities in an All-round Way, Especially to Enhance Students' Abilities and Horizons in Speaking Chinese Stories}

Foreign language is not only a tool of communication, but also a carrier of culture. At present, in addition to public foreign languages in Chinese universities and colleges, the courses of other foreign languages are generally aimed at western culture. It lacks the courses of Chinese culture taught in foreign languages. And the main body of classroom learning is lost. It is necessary to gradually increase the courses of Chinese traditional culture, Sinology and the comparison of Chinese and western cultures in capable universities. At the same time, the colleges and universities can also develop the Chinese culture into existing curriculum. For example, in the course of reading, the teachers should appropriately introduce English materials on Chinese culture, English translations and works on China. Chinese elements that mainly reflect Chinese politics, economy, culture, society and people's livelihood should be added to the translation courses and listening courses. The content of classroom lectures should be flexible. And it should contain cultural content with Chinese characteristics and local characteristics. Through the comparison of Chinese and western cultures, it enables students to master some methods of Chinese traditional expression. It would enhance students cultural confidence and ability to express Chinese culture in foreign languages. It also would promote the output of the language and culture. And it could stimulate the will of cultural exchange and dissemination. In foreign language education of colleges and universities, it urgently needs to expand the humanistic connotation and pay more attention to the introduction of culture. It is the mission of serving the national strategy. And it is also the essential requirement of humane quality education.

\section{To Establish Critical View in Foreign Language}

Education of Colleges and Universities, and to Guide Students to View Foreign Culture with Correct Values and Methodology

Through cultural contrast, the teachers should encourage students to establish critical awareness and critical thinking. And then, the students would objectively analyze and treat foreign cultures. Through the reflection of different cultures and fusion of sight, Chinese culture will be sent to the other side of the world. Foreign language teaching should emphasize social orientation, supplement native culture, carry out the practice of cultural discourse and promote value recognition. The learners should tell Chinese stories. And it would promote conciseness of Chinese discourse and carry forward the value of China. The students would become a new generation with cultural consciousness and cultural confidence. Foreign language teachers should have broader knowledge and lead students to grasp the politics, economics and cultures deeply. At home and abroad, the students should form the correct values, and the sense of honor and recognition of Chinese culture. Foreign language teachers in colleges and universities should enhance their cultura accomplishment and discernment. They should break through the path dependence, guide students to form cultural discrimination, and encourage students to participate in the academic research and exchanges on Chinese and foreign cultures. The teachers should increase the introduction of comparative cultural methodology. The students would complete the cultural introspection, cultural consciousness and cultural confidence. 
D. To Consolidate the Foundation of Foreign Language Education in Colleges and Universities Based on the Construction of Foreign Language Teaching Resources System in Contemporary Society

Teaching resource is the foundation to carry out the education and teaching activities. Teaching resources should expand the "Chinese language" and native culture. In terms of teaching materials, almost all the foreign language teaching materials in China are selected from the original foreign publications. These materials introduce the content of foreign politics, economy, culture and social life. There is little knowledge on the local customs and practices of China. Foreign language teaching materials should be supplemented with some Chinese elements. And these materials should keep pace with the times. Also, they could introduce foreign language books that reflect the Chinese culture. In terms of teaching materials, in addition to the exotic culture, the teachers should further promote local culture, tap foreign language teaching resources in China, and enhance learners' understanding of different cultural discourses. The established cultural attitudes should be equal, tolerant, cooperative and win-win. In terms of information resources, the teachers can adopt either the form of second classroom or three-dimensional teaching method of "classroom + network". The teachers should encourage learners to start the discussion on Chinese discourse in the classroom. Based on the platform of internet, it would conducive to the reflections of Chinese discourse. And it would promote language skills and dual confidence. In the aspect of translation norms of Chinese language, it is necessary to further standardize the foreign language expression of Chinese words with Chinese characteristics. It should penetrate the foreign language expression education of Chinese culture into foreign language teaching at all levels, reduce the misreading and enhance confidence in future foreign affairs activities.

\section{CONCLUSION}

Under the current circumstances, the main task of foreign language education should be to bring Chinese culture to the world and achieve cultural innovation in the exchange and collision between Chinese and Western cultures. Also, the colleges and universities should cultivate students' cultural awareness and establish learners' cultural confidence. The cultivation of cultural awareness in foreign language education will not only lay solid foundation for the establishment of students' "cultural confidence", but also lay solid national foundation for the "cultural strength".

\section{REFERENCES}

[1] To build moderately prosperous society, to win great victory of socialism with Chinese characteristics in the new era [M]. People's Publishing House, 2017.

[2] Yuan Xiaolu, Zhao Juan, Dong Mei. A study on the current situation and attribution of culture consciousness in foreign language education [J]. Foreign Language Education, 2017 (3): 56-61.

[3] Zhang Bei, Ma Lan. A study on the cultural content of college English textbooks [J]. Foreign Language World, 2004 (4): 60-66.

[4] Liu Kehong. Study on the cultural orientation of foreign language education - A review on American cultural orientation in reading and writing course "New Horizon College English" [J]. Modern University Education, 2005 (4): 99-102.

[5] Yuan Xiaolu, Zhao Juan. The appeal and response of cultural cultivation in foreign language education under "the Belt and Road Initiative" [J]. Journal of Xi'an International Studies University, 2017 (3): 69-72.

[6] William von Humboldt. Humboldt Philosophy of Literary Collections [M]. The Commercial Press, 2011.

[7] Luo Qingxu. On critical thinking training of college students [J]. Education Research of Tsinghua University, 2000 (4): 81-85.

[8] Cong Cong. "Chinese culture aphasia": the defects of Chinese English teaching [N]. Guangming Daily, 2000-10-19. 